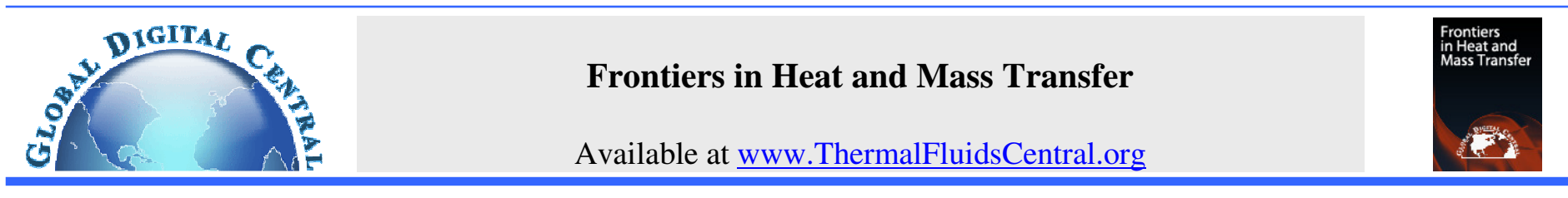

\title{
ANALYSIS OF COMBUSTION MECHANISM AND COMBUSTION OPTIMIZATION OF A 300MW PULVERIZED COAL BOILER
}

\author{
Xiaoqian Ma ${ }^{\text {a }}$, Mo Yang ${ }^{\mathrm{a},}$, , Yuwen Zhang ${ }^{\mathrm{b}}$ \\ ${ }^{a}$ School of Energy and Power Engineering, University of Shanghai for Science and Technology, Shanghai, 200093, China \\ ${ }^{b}$ Department of Mechanical \& Aerospace Engineering, University of Missouri, Columbia, Missouri, MO 65211, USA
}

\begin{abstract}
Combustion mechanism of a $300 \mathrm{MW}$ pulverized coal boiler is analyzed and the optimization of the performance of the boiler is carried out. The flow field, temperature field, devolatilization, char combustion and $\mathrm{CO}$ generation in the boiler furnace under actual condition is obtained by using Fluent. Three methods to improve the efficiency of boiler combustion are proposed based on the pulverized coal combustion mechanism; their feasibilities are verified through numerical simulation and analysis. The three proposed methods to increase the combustion efficiency may give theoretical reference for air arrangement and combustion optimization of the same type of burners.

Keywords: Utility pulverized coal fired boilers, Combustion efficiency, Combustion mechanism, Numerical simulation.
\end{abstract}

\section{INTRODUCTION}

Although hydroelectricity and wind power generation in China have been developing, the electric power market in China gives priority to thermal power generation (Wu, 2013; Jia and Yang, 2014), of which about $70 \%$ is coal-fired power unit because of China's "rich in coal, poor in oil and gas" energy pattern (Yan, 1996). Most coal-fired power plants use pulverized coal combustion boiler. Working condition of pulverized coal combustion boiler is very complex, involving combustion, flow and heat transfer processes, and the problem of high energy consumption and low combustion efficiency is very common (Sheng, 2013). These problems directly affect the security and economy of power plant boiler operation.

Chen et al. (2002) performed combustion optimization for a tangentially pulverized coal fired boiler with design defects by adjusting the proportion of each section in boiler heating surface. Wang et al. (2010) analyzed the cause of high mechanical incomplete combustion heat loss in a circulating fluidized bed boiler through studying the influence factors of fly ash and bottom ash carbon content. Cui (2013) analyzed the form and influence factors of the heat loss in coal fired boiler, and put forward several optimization measures according to the actual situation. Liu et al. (2003) deduced the pulverized coal boiler combustion efficiency analysis model through a series of simplification and assumption. Lv (2013) summarized some measures to improve the boiler efficiency from practical experience.

Chemical reactions of pulverized coal combustion is pretty complex, only by studying the mechanism of combustion can we fundamentally summarize the regularities of pulverized coal complete combustion and less $\mathrm{CO}$ generation, so as to improve the combustion efficiency. So it is necessary to understand the coal combustion mechanism. Dou et al. (2007) simulated the combustion process of pulverized coal under different injection velocities to study anthracite combustion mechanism, and suggested that the main combustion mechanism of the anthracite coal in calciner is mixed-diffusion rate control combustion. Xie et al. (2005) and He et al. (2009) performed numerical simulations on the combustion process of pulverized coal in calciner and rotary kiln, respectively; the results revealed the volatile release and combustion process as well as analyzed the combustion mechanism of char. Ariyama et al. (1994) obtained combustion mechanism by using high speed camera to observe the combustion process in the furnace directly. Wang et al. (1996) introduced several main processes of fuel particles combustion in internal circulating fluidized bed, and proposed a model of fuel particles combustion efficiency. $\mathrm{Wu}$ (2014) and $\mathrm{Li}$ et al. (2013) studied combustion mechanism and dynamic characteristics of pulverized coal in fluidized bed boiler through experiments.

However, there are few literatures about combustion efficiency optimization from the view point of combustion mechanism. In this paper, we simulate the actual working condition at first, and analyze the flow field, temperature field, devolatilization, char combustion and $\mathrm{CO}$ generation in the boiler furnace, and propose three methods to improve the efficiency of boiler combustion from the angle of pulverized coal combustion mechanism, and then verify their feasibility through numerical simulation and analysis. The results may give theoretical reference for air arrangement and combustion optimization of the same type of burners.

\section{MODEL ESTABLISHMENT AND NUMERICAL SIMULATION}

\subsection{Geometric Model}

The full scale geometric model is established for numerical simulation based on a 300MW power plant boiler. The boiler is B\&WB1025/17.5-M type single furnace, single drum, swirl flow hedge boiler. Take bottom ash hopper to the area before air preheater as computational domain, and the furnace outlet is the area after superheater. Front wall is arranged with three layers of burners, back wall is arranged with two layers of burners, the front and back wall are respectively arranged with a layer of SOFA air vent, as shown in Fig. 1. The first layer is DRB-4Z burner, the second and third layer is AireJet burners, air duct structure of the burners are shown in Figs. 2 and 3 respectively. There are 4 layers of airflow tunnels in DRB- $4 Z$ burner: primary air, transition secondary air, inner secondary air and outer

\footnotetext{
* Corresponding author. Email: yangm@usst.edu.cn
} 
secondary air (from inside to outside). Primary air and transition secondary air is direct flow, inner and outer secondary air is swirling. There are 4 layers of airflow tunnels in AireJet burner: central air, primary air, inner secondary air and outer secondary air (from inside to outside). Central air and primary air is direct flow, inner and outer secondary air is swirling.

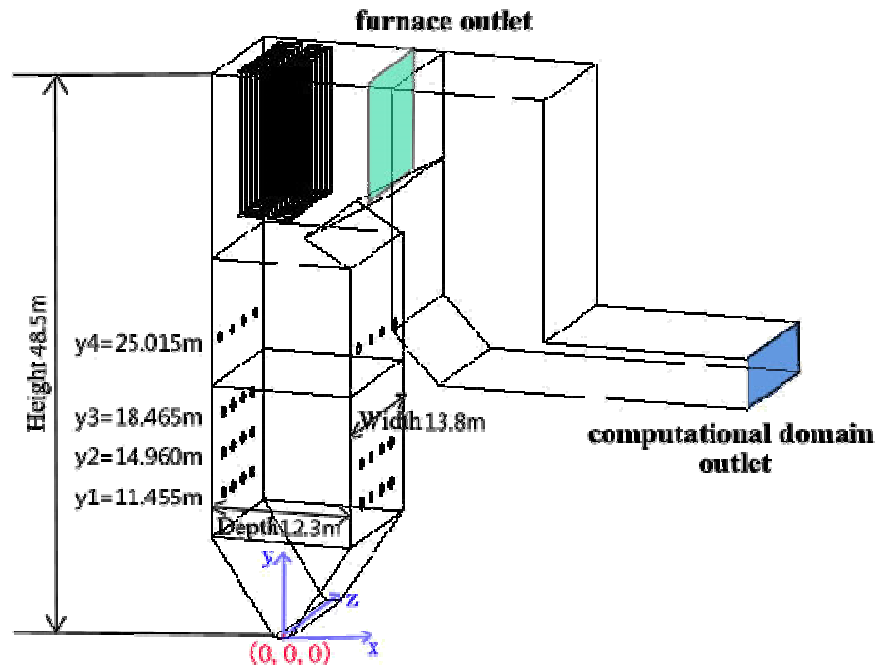

Fig. 1 Geometry of the boiler

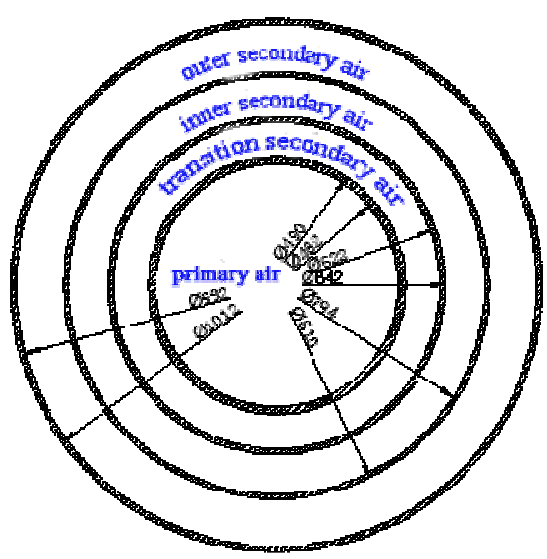

Fig. 2 DRB-4Z burner air duct structure

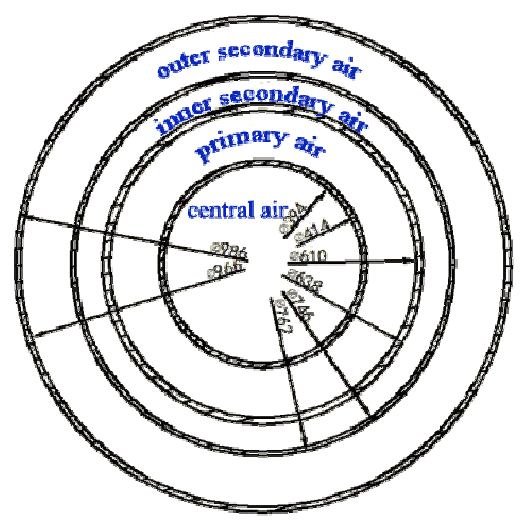

Fig. 3 AireJet burner air duct structure

The grid of computational domain is shown in Fig. 4. The whole space is divided into bottom ash hopper zone, the main combustion zone, SOFA air zone, superheater zone and the tail flue duct zone. ICEM is used to meshing with structured hexahedral mesh, and the grid of main combustion zone and SOFA wind zone is denser. The total number of grid is about 2.2 million.

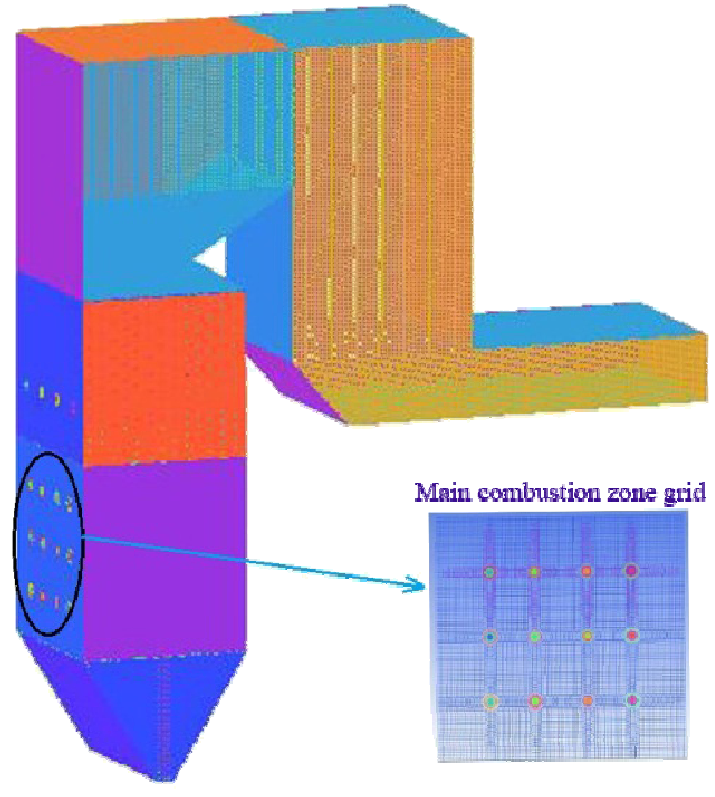

Fig. 4 Grid division

\subsection{Mathematical Model}

\subsubsection{Boundary conditions}

Boundary conditions are set according to the actual operating conditions. The burner nozzle and the SOFA air nozzle are as velocity inlet boundary condition, as shown in Table 1. Only the corresponding four coal mills of the first and the second layer burner are in operation, and only the secondary air is injected through the third layer burner. Non-slip boundary is set on the wall of the furnace, and wall temperature is segmentally given according to the actual situation. The tail flue duct zone is set as adiabatic boundary condition due to the onarrangement of the heating surface. Diameter of pulverized coal is in accordance with the Rosin-Rammler distribution (Zheng et al., 2006), ranging from $10 \mu \mathrm{m}$ to $300 \mu \mathrm{m}$.

Table 1 Air distribution of each burner on actual operation condition

\begin{tabular}{|c|c|c|c|}
\hline Burners & Coal (t//h) & $\begin{array}{c}\text { Primary air } \\
(\mathbf{t} / \mathbf{h})\end{array}$ & $\begin{array}{c}\text { Secondary air } \\
(\mathbf{t} / \mathbf{h})\end{array}$ \\
\hline $\begin{array}{c}\text { The first layer of front } \\
\text { wall burner }\end{array}$ & 30.68 & 61.33 & 107.37 \\
\hline $\begin{array}{c}\text { The first layer of back } \\
\text { wall burner }\end{array}$ & 32.28 & 63.6 & 145.55 \\
\hline $\begin{array}{c}\text { The second layer of } \\
\text { front wall burner }\end{array}$ & 31.79 & 62.93 & 118.64 \\
\hline $\begin{array}{c}\text { The second layer of } \\
\text { back wall burner }\end{array}$ & 30.68 & 55.47 & 98.98 \\
\hline $\begin{array}{c}\text { The third layer of } \\
\text { front wall burner }\end{array}$ & 0 & 0 & 67 \\
\hline SOFA air of front wall & & & 219.63 \\
\hline SOFA air of back wall & & & 173.91 \\
\hline
\end{tabular}
Table 2

The element analysis and industry analysis data of coal is shown in

Table 2 Element analysis and industry analysis data of pulverized coal

\begin{tabular}{|c|c|c|c|c|}
\hline \multicolumn{4}{|c|}{ Industrial analysis (Mass percent) } & \multirow{3}{*}{$\begin{array}{l}Q_{\text {net,daf }} \\
(\mathrm{MJ} / \mathrm{kg})\end{array}$} \\
\hline V & $\mathrm{FC}$ & $\mathrm{A}$ & M & \\
\hline 0.2693 & 0.4539 & 0.163 & 0.1138 & \\
\hline \multicolumn{4}{|c|}{ Elemental analysis (Mole percent) } & \\
\hline $\mathrm{C}_{\mathrm{daf}}$ & $\mathrm{H}_{\mathrm{daf}}$ & $\mathrm{O}_{\text {daf }}$ & $(\mathrm{N}+\mathrm{S})_{\mathrm{daf}}$ & \multirow{2}{*}{23.16} \\
\hline 0.8133 & 0.05 & 0.1142 & 0.0225 & \\
\hline
\end{tabular}




\subsubsection{Model Selection}

The commercial package Fluent ${ }^{\circledR}$ has been used to solve the problem. The gas phase turbulence model is the Realizable k- $\varepsilon$ two equation model, and radiation heat transfer model is P-1 radiation model. The discrete phase model is used to simulate the force and motion trajectory of the pulverized coal particles, and the stochastic model is used to simulate the flow of coal particles. The combustion model is nonpremixed combustion model, and the devolatilization model is two competing rates model; char combustion model is kinetics/diffusionlimited model.

\subsection{Numerical Simulation}

The finite volume method is used to solve the gas phase discrete equations, and the difference equations are obtained by the first order upwind format. The SIMPLEC algorithm is used to solve the problem of pressure and velocity coupling of discrete equations. The influence of the discrete phase to continuous phase is considered, and every 50 times of continuous phase iterative calculations, the discrete phase iterate 1 time.

\section{SIMULATION OF THE ACTUAL OPERATION CONDITION}

\subsection{Flow Field Distribution}

Figure 5 shows flow field distribution of the whole furnace and longitudinal section in $\mathrm{Z}$ direction. The overall air flow velocity is small in the main combustion zone, while the air flow velocity of SOFA air zone is increasing gradually. Because the staged combustion strategy is adopted in the boiler to restrain the generation of pollutants, and the overfire air accounted for $33 \%$ of the total air.
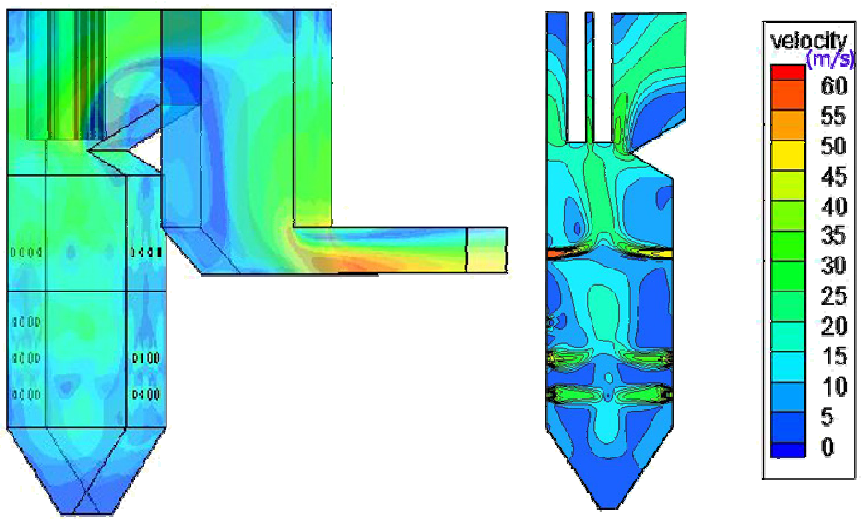

Fig. 5 Flow field distribution of the whole furnace and longitudinal section in $\mathrm{Z}$ direction

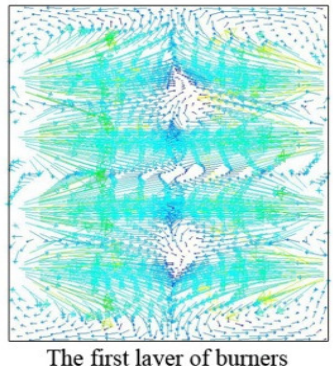

The first layer of burners $\mathrm{Y} 1=11.455$

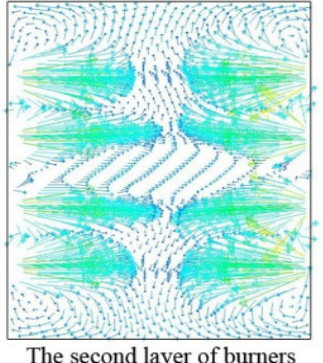

The second layer of burners $\mathrm{Y} 2=14.96$
Fig. 6 Cross section velocity vector of the first and second layer burners

Figure 6 is cross section velocity vector of the first and second layer burners. Figure 7 is cross section flow field distribution in the height of each layer burners and SOFA nozzles. The swirl intensity of the first layer DRB-4Z burner jet is small, so the stiffness of the jet is larger, and the velocity is saddle shaped. And stiffness of direct flow center secondary air in the second layer AireJet burner is very large. Figure 7 shows that there is high temperature flue gas recirculation zone in the flame root of two kinds of burners, which is conducive to ignition of pulverized coal carried by primary air. The swirling secondary air injected into the furnace through third layer burner has little influence on the original flow field. SOFA velocity is pretty large, and has strong penetrating power.

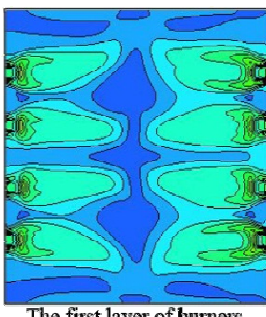

The first layer of burners $Y 1=11.455$

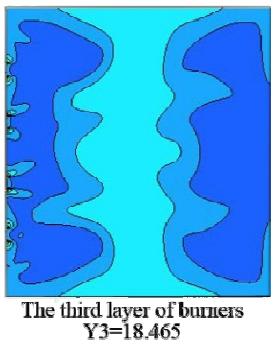

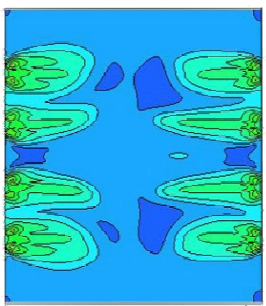

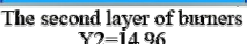
$\mathrm{Y} 2=14.96$

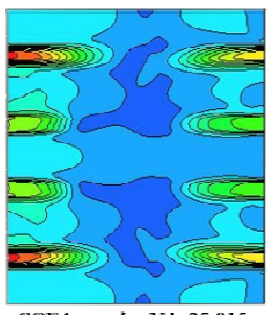

SOFA nozzles $\mathrm{Y} 4=25.01$

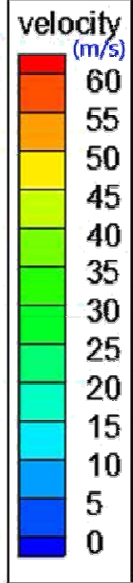

Fig. 7 Cross section flow field distribution in the height of each layer burners and SOFA nozzles

\subsection{Temperature Field Distribution}

Figure 8 is temperature distribution of longitudinal section in $\mathrm{X}$ direction and $\mathrm{Z}$ direction in furnace.
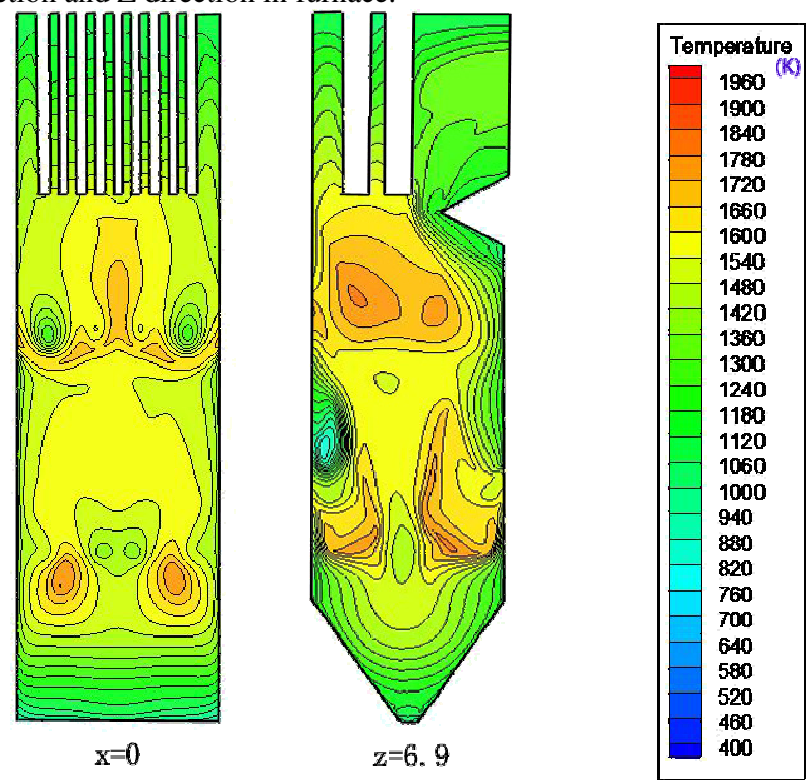

Fig. 8 Temperature distribution of longitudinal section in $\mathrm{X}$ direction and $\mathrm{Z}$ direction in furnace

We can find that the flame fullness is good, and the combustion reaction occurs in the whole furnace. The maximum temperature of the furnace is $2029.79 \mathrm{~K}$, which is located near the first and the second layers of burner in main combustion zone, and the average temperature of the furnace is $1315.86 \mathrm{~K}$. The high temperature zone in the furnace concentrate is around the main combustion zone near the burner and burnout zone near the SOFA nozzle. Because the staged combustion strategy is adopted in the boiler to reduce the pollutants, result in excess air coefficient in the main combustion zone is very small, about 0.6 Pulverized coal not completely burnt in the main combustion zone 
continues to burn in the SOFA air zone. In addition we can see a local low temperature zone near the front wall, due to the mills of the third layer burners is closed, only the secondary air is injected into the furnace, which is much lower than flue gas temperature, so the third layer near the burner nozzle appear local low temperature.

Figure 9 is cross section temperature field distribution in the height of each layer burners and SOFA nozzles. We can see that compared with AireJet burner, the ignition distance of DRB-4Z burner is longer, and the distribution of high temperature zone is more concentrated. This is because swirl intensity of the inner and outer secondary air is greater in the AireJet burners, therefore the flame stiffness is smaller, and the flame is closer to the front and back wall surface. And because the central air pipe is arranged in AireJet burner, combining with the analysis of the flow field in 3.1, there is a high temperature flue gas recirculation zone in front of primary air outlet, so primary air is surrounded by high temperature flue gas and hot secondary air together, and thus pulverized coal ignition is earlier than DRB-4Z burner. Only the secondary air is injected through the third layer burner, and secondary air temperature is about $595 \mathrm{~K}$, so there is local low temperature near the nozzle as mentioned before. SOFA air has large stiffness, strong penetrability, and supplements the lack of air, so that the unburnt pulverized coal continues to burn. The flame fullness is good in SOFA zone.

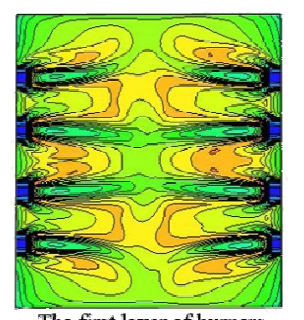

The first layer of burners $Y 1=11.455$

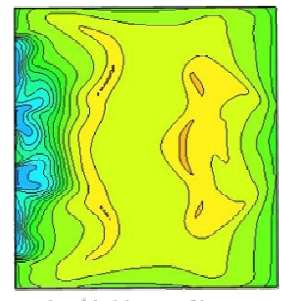

The third layer of burner $\mathrm{Y} 3=18.465$
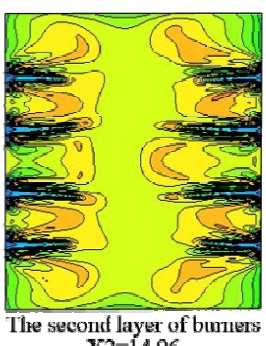
$\mathrm{Y} 2=14.96$

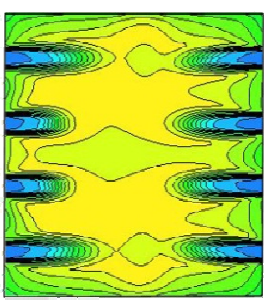

SOFA nozzles $\mathrm{Y} 4=25.015$

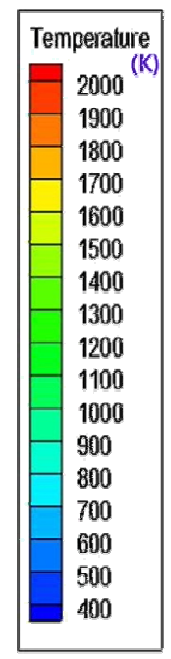

Fig. 9 Cross section temperature field distribution in the height of each layer burners and SOFA nozzles

As shown in Fig. 10 is section average temperature along the furnace height distribution. On the height of each layer of burners, temperature has a valley value due to cold air injection. The high temperature zone in the furnace is mainly concentrated in the main combustion zone.

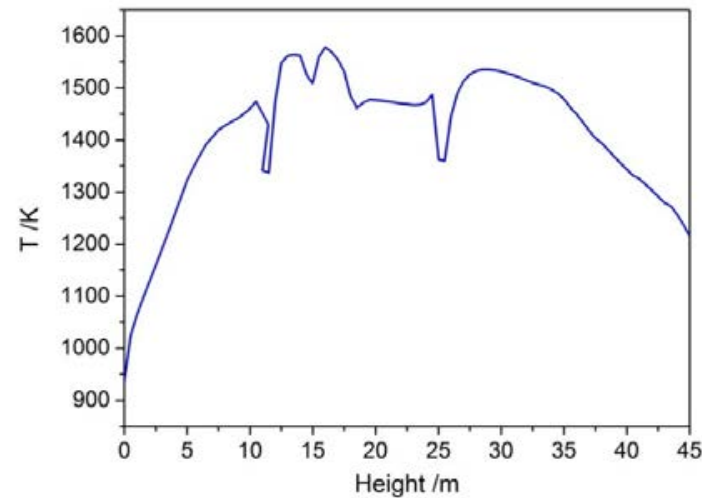

Fig. 10 Section average temperature along the furnace height distribution

\subsection{Char Burnout Rate and CO Generation}

Boiler combustion efficiency refers to the ratio of fuel burning heat to fuel chemical energy (Sun et al., 2001), thus combustion heat loss that affects combustion efficiency is $\mathrm{Q}_{3}$ for gas incomplete combustion heat loss and $\mathrm{Q}_{4}$ for solid incomplete combustion heat loss. Gas incomplete combustion heat loss can be reflected by $\mathrm{CO}$ concentration, while solid incomplete combustion heat loss can be show as char burnout rate.

Therefore, improving char burnout rate and reduce $\mathrm{CO}$ concentration of the furnace outlet is helpful to improve the combustion efficiency of the boiler, Table 3 is $\mathrm{CO}$ concentration and Char burnout rate of calculation domain outlet, the char burnout rate is $96.44 \%, \mathrm{CO}$ concentration is $0.2167 \%$, with a certain optimization space.

Table $3 \mathrm{CO}$ concentration and Char burnout rate of calculation domain outlet

\begin{tabular}{|c|c|}
\hline CO concentration $(\boldsymbol{\%})$ & Char burnout rate $(\boldsymbol{\%})$ \\
\hline 0.2167 & 96.44 \\
\hline
\end{tabular}

Figure 11 is char concentration distribution of longitudinal section in $\mathrm{X}$ direction and $\mathrm{Z}$ direction in furnace. Char is mainly concentrated in the main combustion zone, and peak value of the char concentration is located between the front and back wall in the main combustion zone. Because $\mathrm{O}_{2}$ near the front and back wall burners are adequate, conducive to the combustion of char, and to the center of the furnace $\mathrm{O}_{2}$ has been depleted. Char concentration of bottom ash hopper zone is high, and significantly reduce at SOFA air zone. Because $\mathrm{O}_{2}$ is complemented by SOFA air, promoting the char combustion reaction.

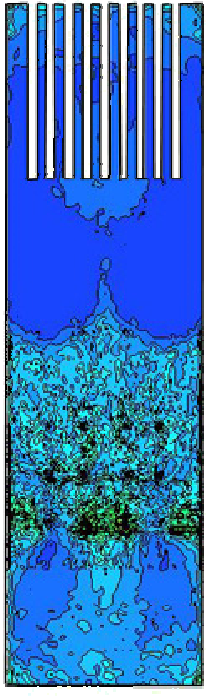

$\mathrm{x}=0$

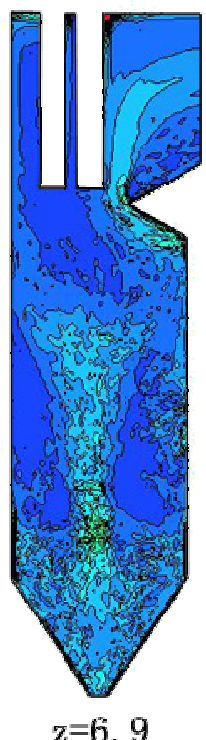

$\mathrm{z}=6.9$

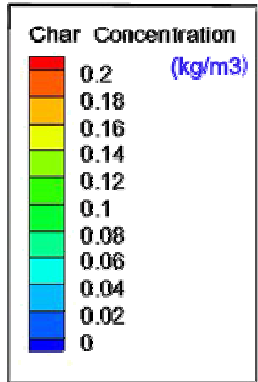

Fig. 11 Char concentration distribution of longitudinal section in $\mathrm{X}$ direction and $\mathrm{Z}$ direction in furnace

The main approach of $\mathrm{CO}$ generation is the production of incomplete combustion of char and the release of volatile, and the main way of $\mathrm{CO}$ consumption is $\mathrm{O}_{2}$ reaction with $\mathrm{CO}_{2}$. When producing rate $>$ consumption rate, $\mathrm{CO}$ concentration increase; when producing rate $<$ consumption rate, $\mathrm{CO}$ concentration decrease.

Figure 12 is $\mathrm{CO}$ concentration distribution of longitudinal section in $\mathrm{X}$ direction and $\mathrm{Z}$ direction in furnace. $\mathrm{CO}$ concentration of bottom ash hopper zone is high, and reductive atmosphere created in order to reduce pollutants make $\mathrm{CO}$ concentration at higher values in the main combustion zone, then $\mathrm{O}_{2}$ is complemented by SOFA air, and $\mathrm{CO}$ concentration decreased sharply. 


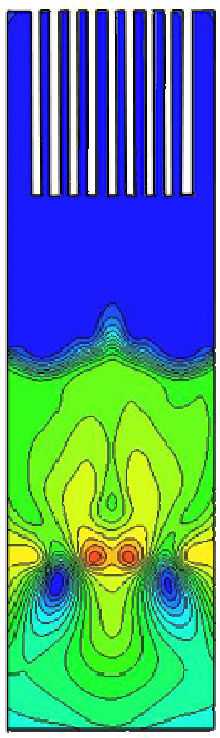

$\mathrm{X}=0$

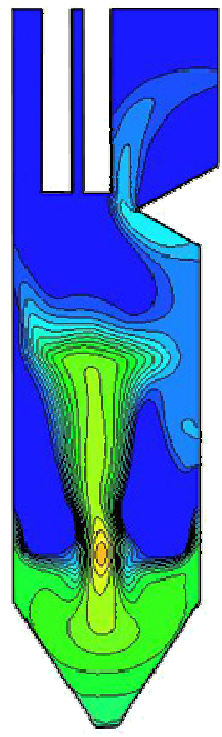

$\mathrm{z}=6.9$
Fig. $12 \mathrm{CO}$ concentration distribution of longitudinal section in $\mathrm{X}$ direction and $\mathrm{Z}$ direction in furnace

Figure 13 is $\mathrm{CO}$ concentration, char concentration curve along the furnace height. The figure shows that every valley value of $\mathrm{CO}$ concentration is at each burner nozzle height. Because near the burner, on one hand, $\mathrm{O}_{2}$ injection itself will cause the loss of $\mathrm{CO}$ concentration percentage; on the other hand, $\mathrm{CO}$ consumed by reacting with $\mathrm{O}_{2}$ injected. Char concentration is very high in the hopper, the two peaks of char concentration is located at the first and second layers of burners in the main combustion zone. Because the primary air injected from the first and second layers of burners carries pulverized coal injection into the furnace. Above the main combustion zone with the increasing of the height, the char concentration oscillating drop, and at the SOFA air vents, as mentioned before, the char concentration begins to decline sharply.

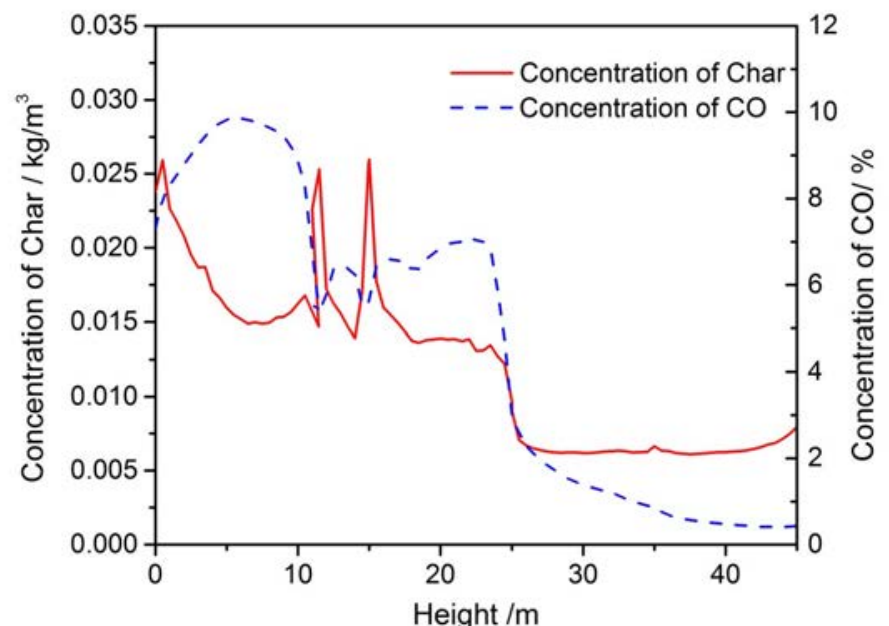

Fig. $13 \mathrm{CO}$ concentration, char concentration curve along the furnace height

\subsection{Comprehensive Analysis of Combustion Mechanism}

Figure 14 illustrates the volatile release only near the first and second layers of burners and burn out quickly, char is partial combusted near the first and second layers of burners, the rest is mainly combusted in SOFA air zone. Therefore, $\mathrm{CO}$ is mainly produced by incomplete combustion of char.

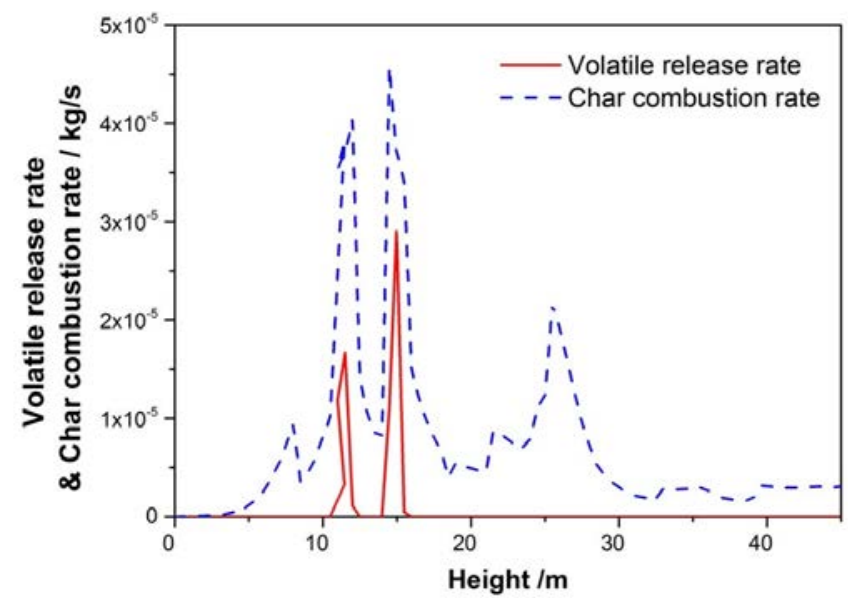

Fig. 14 Volatile release speed and char burning speed curve along the furnace height

As the coal is a mixture of complex composition, the intermediate reaction occurred in combustion is complex. For the convenience of analysis we don't consider the complex intermediate products temporarily, only study the most basic and important reaction.

The main chemical reactions of pulverized coal combustion:

Volatile $+\mathrm{O}_{2} \rightarrow \mathrm{CO}_{2}+\mathrm{H}_{2} \mathrm{O}+\mathrm{N}_{2}$

$\mathrm{C}+0.5 \mathrm{O}_{2} \rightarrow \mathrm{CO}$

$\mathrm{CO}+0.5 \mathrm{O}_{2} \rightarrow \mathrm{CO}_{2}$

$\mathrm{C}+\mathrm{CO}_{2} \rightarrow 2 \mathrm{CO}$

$\mathrm{C}+\mathrm{H}_{2} \mathrm{O} \rightarrow \mathrm{H}_{2}+\mathrm{CO}$

$\mathrm{H}_{2}+0.5 \mathrm{O}_{2} \rightarrow \mathrm{H}_{2} \mathrm{O}$

As mentioned above, volatile released and burnt out soon near the burners, and the water vapor and $\mathrm{H}_{2}$ concentration is very low, so main reactions in the furnace is [2][3][4].

Figure 15 shows, at each layer of the burners' height, due to the injection of $\mathrm{O}_{2}, \mathrm{O}_{2}$ concentration has a peak, and $\mathrm{CO}, \mathrm{CO}_{2}$ and $\mathrm{C}$ concentrations have a valley value.

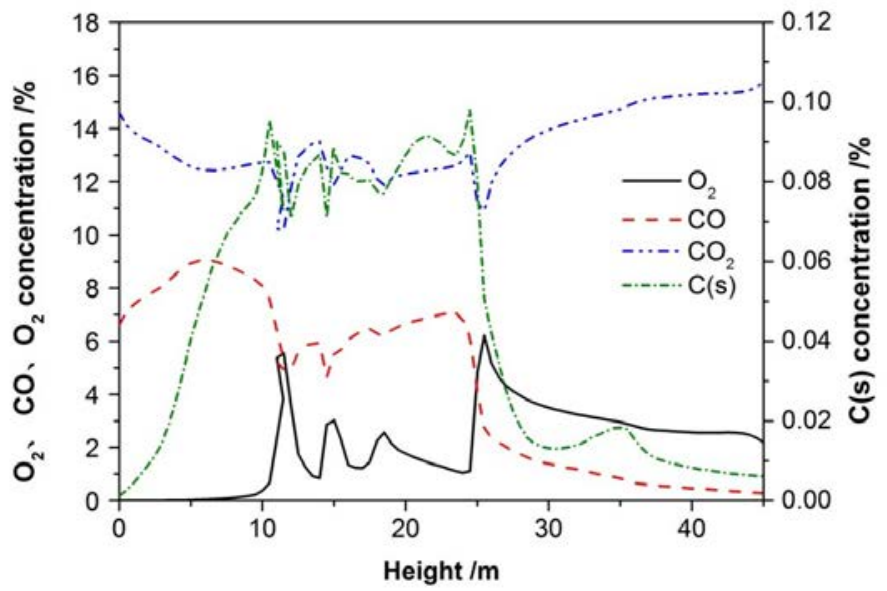

Fig. 15 Concentration of $\mathrm{CO} 、 \mathrm{CO}_{2} 、 \mathrm{O}_{2} 、 \mathrm{C}(\mathrm{s})$ along the furnace height

Before Y1, namely the area from ash hopper to the first layer of the burners, $\mathrm{O}_{2}$ concentration is extremely low, the main reaction is reaction [4], so the concentration of $\mathrm{CO}$ increased, while $\mathrm{CO}_{2}$ concentration decreased. Between Y1 and Y2, namely between the first and the second layer burners, pulverized coal and $\mathrm{O}_{2}$ injected through burners, and because the temperature is not too high, about $1400 \mathrm{~K}$, the reaction activation energy and reaction [4] is very high, only the temperature reaching $1300^{\circ} \mathrm{C}$ or more will the reaction carry on easily, thus the main reaction is [2] and [3]. Between Y2 and Y4, that is, between the second layer of the burners and SOFA air vents, CO concentration oscillating increase, and $\mathrm{CO}_{2}$ concentration oscillating 
decrease, and the temperature here is high, about $1600 \mathrm{~K}$, the reaction [2][4] is dominant. After Y4, namely the burnout zone, as a result of the complement of $\mathrm{O}_{2}$, the main reaction is [2][3], concentration of $\mathrm{CO}, \mathrm{O}_{2}$ and $\mathrm{C}$ decreased rapidly, $\mathrm{CO}_{2}$ concentration increased rapidly. And the concentration of $\mathrm{CO}$ and $\mathrm{C}$ fall before $\mathrm{Y} 4$ at $\mathrm{Y}=23 \mathrm{~m}$, this is due to swirling overfire air injected through the SOFA nozzles spread to the zone, prompting the reaction [2] and [3].

In order to further study reaction mechanism near the nozzle, the author draws volatile and char combustion speed curve and component change curve of the first layer and the second layer along the direction of the flow ejected from burners, see Fig. 16, Fig. 17, Fig. 18, and Fig. 19.

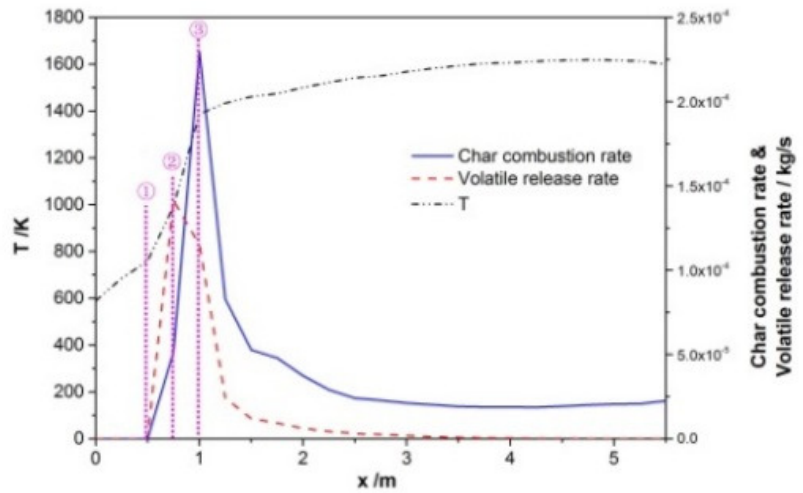

Fig. 16 Char burning speed, volatile release speed and temperature variation of the first layer DRB-4Z burner along the air flow direction

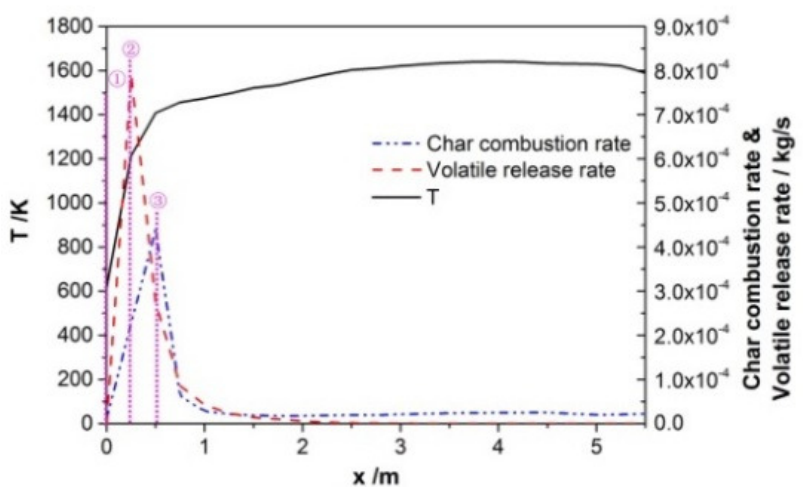

Fig. 17 Char burning speed, volatile release speed and temperature variation of the second layer AireJet burner along the air flow direction

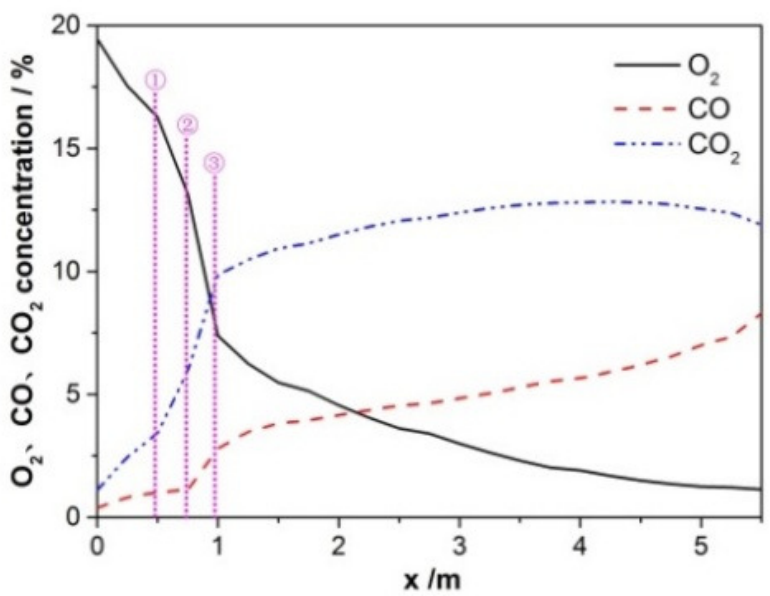

Fig. 18 Concentration of $\mathrm{O}_{2}, \mathrm{CO}$ and $\mathrm{CO}_{2}$ of the first layer DRB-4Z burner along the air flow direction

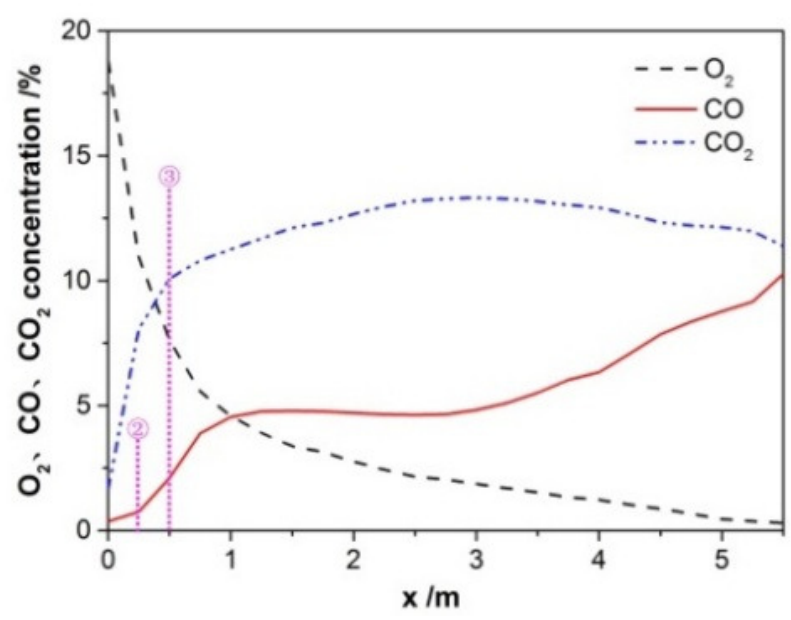

Fig. 19 Concentration of $\mathrm{O}_{2}, \mathrm{CO}$ and $\mathrm{CO}_{2}$ of the second layer AireJet burner along the air flow direction

Through comprehensive analysis of all these pictures, volatile and char start burning almost at the same time, due to the volatile ignition temperature is about $540 \mathrm{~K}$, and temperature of near burner area where volatile begins to release is about $600 \mathrm{~K}$, so volatile start burning immediately once released. The volatile release rate reach peak value before the char combustion rate, because volatile combustion is gas phase reaction and char combustion is the gas-solid reaction, char is at a disadvantage in competition for $\mathrm{O}_{2}$ clearly, namely volatile prevent char burning. But on the other hand, devolatilization increase the inner hole of char particles, which increase the specific surface area, and volatile combustion provides the required heat of char ignition, so the release and combustion of volatile also promote char combustion. But before the release rate of the volatile reach the peak value, the blocking effect was dominant, and the promoting effect was dominant after the release rate reach the peak. Volatile and char combustion make temperature increase sharply, and then rise slowly after char combustion rate reach to peak value. No matter it is volatile release, or char combustion, the second layer AireJet burner is earlier than the first layer DRB-4Z burner. This is because secondary air swirl intensity of AireJet burner is larger as well as the arrangement of central air, promoting radial air-coal mix and heat transfer with hot flue gas, therefore, char and volatile burn as soon as possible, and the peak value of volatile release rate and char combustion rate is much higher than DRB- $4 \mathrm{Z}$ burner.

\subsection{Summary of Boiler Combustion Optimization}

We want to reduce $\mathrm{CO}$ and improve char burnout rate. at the outlet of furnace without increasing the amount of $\mathrm{NO}_{x}$ produced. In order to control the production of $\mathrm{NO}_{x}$, staged combustion strategy is adopted in the boiler to create reductive environment in the main combustion zone, so the excess air coefficient in the main combustion zone cannot be increased.

Although a plenty of air is injected into furnace at the burnout zone promoting the combustion of char and $\mathrm{CO}$, but this zone is close to the furnace outlet, incompletely combusted fuel may not have enough time for the combustion reaction before the furnace outlet, although total excess air coefficient is greater than 1, there are still unburnt char and $\mathrm{CO}$ at the furnace outlet. Therefore, to promote burnout of char and $\mathrm{CO}$, we should optimize the combustion of main combustion zone first. And from the analysis of 3.4 section we can know that, $\mathrm{CO}$ is produced mainly in the main combustion zone, so we should find ways to suppress the generation of $\mathrm{CO}$ at the main combustion zone.

Figure 15 shows that although $\mathrm{O}_{2}$ concentration in main combustion zone remains at a low level, but it is not exhausted, indicating the reactions of char and $\mathrm{CO}$ with $\mathrm{O}_{2}$ is not thorough. Combined with the analysis of combustion mechanism in the burner region, we speculate the reason may be the air-coal mixing is not good 
enough; on the other hand, it may be that the pulverized coal residence time is too short to complete reaction.

As mentioned above, the high temperature zone in the furnace is mainly concentrated in the main combustion zone. If we want the pulverized coal catch fire as soon as possible, we must get longer stay time for the fuel in high temperature area, which is helpful to the combustion reaction. Therefore, we can rise pulverized coal-air flow temperature properly through increasing primary air temperature, thus reducing ignition heat. Ignition heat can also be reduced by reducing the air-coal ratio (mass ratio of primary air to pulverized coal), that is, reducing the flow rate of primary air, so that fuel catching fire ahead of schedule. We also can increase swirl intensity of the secondary air to increase entrainment quantity of the hot flue gas and enhance the coalair radial mix.

\section{COMBUSTION EFFICIENCY OPTIMIZATION}

In Section 3, we put forward three possible ways to improve combustion efficiency and the three methods will be verified through numerical simulation in this section.

\subsection{Three Optimization Condition}

In order to ensure comparability of calculation results, we use the single variable method, namely only one parameter is changed each time on the basis of the actual operation condition. Three optimization conditions are shown in Table 4.

Table 4 Adjustment methods of optimization condition

\begin{tabular}{c|c}
\hline $\begin{array}{c}\text { Optimization } \\
\text { condition }\end{array}$ & Adjustment methods \\
\hline Condition 1 & Primary air temperature rises from 350K to 380K \\
\hline Condition 2 & Air-coal ratio decreases from 1.9 to 1.6 \\
\hline Condition 3 & Enhance swirl intensity of outer secondary air \\
\hline
\end{tabular}

\subsection{Char burnout rate and $\mathrm{CO}, \mathrm{NO}_{x}$ generation}

The comparison among the calculation results of three optimization conditions and the actual operation conditions is shown in Table 5. Clear, compared with the actual working condition, char burnout rate at furnace outlet of three optimization conditions is improved more or less, as well as the $\mathrm{CO}$ concentration at furnace outlet decrease, and cause no increase of $\mathrm{NO}_{x}$. The working condition 2 is most obvious. Because aircoal ratio in working condition 2 is significantly reduced, cutting down the ignition heat. At the same time, the residence time of pulverized coal in the main combustion zone is prolonged by reducing the primary air velocity. In the actual operation, primary air flow rate cannot be too low, otherwise there will not be enough oxygen in the early stage of pulverized coal ignition, so that the chemical reaction rate slow down, hindering the continued expansion of the burning. In addition, primary air flow rate must also meet the requirements of the powder transportation; otherwise it will cause a blockage of the pulverized coal.

Table 5 Comparison among the calculation results of three optimization conditions and the actual operation conditions

\begin{tabular}{c|c|c|c}
\hline $\begin{array}{c}\text { Operation } \\
\text { conditions }\end{array}$ & $\begin{array}{c}\text { CO concentration } \\
(\boldsymbol{\%})\end{array}$ & $\begin{array}{c}\text { Char burnout } \\
\text { rate (\%) }\end{array}$ & $\begin{array}{c}\mathbf{N O}_{\boldsymbol{x}} \\
\text { concentration }(\boldsymbol{\mu L} / \mathbf{L})\end{array}$ \\
\hline $\begin{array}{c}\text { Actual } \\
\text { condition }\end{array}$ & 0.2167 & 96.44 & 263.64 \\
\hline Condition 1 & 0.1374 & 96.47 & 268.29 \\
\hline Condition 2 & 0.0695 & 99.25 & 263.95 \\
\hline $\begin{array}{c}\text { Condi } \\
\text { tion 3 }\end{array}$ & 0.1513 & 98.37 & 263.45 \\
\hline
\end{tabular}

Figures 20 and 21 are char concentration and CO concentration of three optimization conditions and the actual operation condition along the furnace height respectively. The figures show that char and CO concentration in the main combustion zone under the three optimized working conditions is lower than that of the actual working condition. So after $\mathrm{O}_{2}$ complemented at the burnout zone, char and $\mathrm{CO}$ burnout rate burning rate is relatively high. This reflects the previous speculation, and the previous analysis of the combustion mechanism has certain reference value.

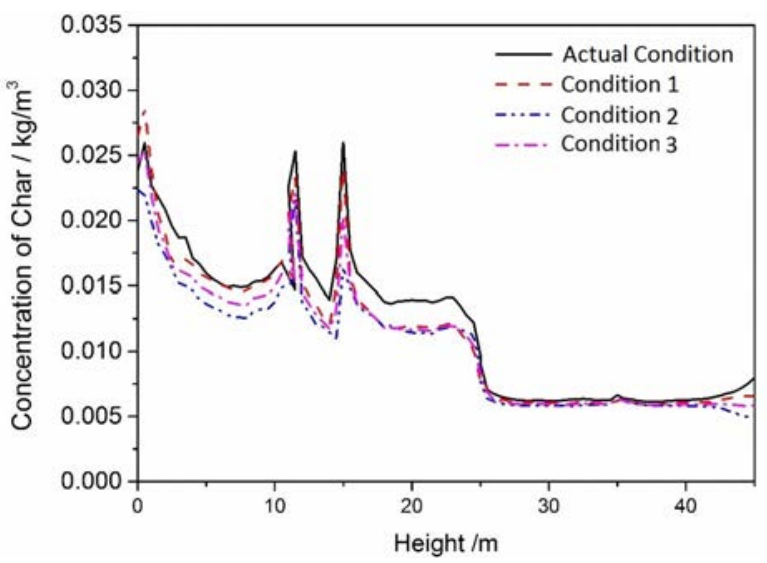

Fig. 20 Char concentration of three optimization conditions and the actual operation condition along the furnace height

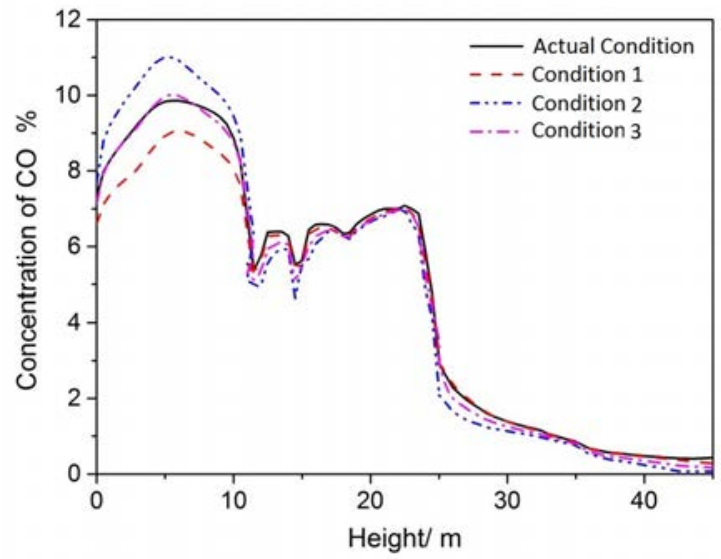

Fig. $21 \mathrm{CO}$ concentration of three optimization conditions and the actual operation condition along the furnace height

\section{CONCLUSIONS}

Based on the numerical simulation research, the following conclusions are drawn:

(1) The flow field and the temperature field distribution in the furnace is reasonable, the flame fullness is good.

(2) Volatile release only near the first and second layers of burners and burn out quickly, char is partial combusted near the first and second layers of burners; the rest is mainly combusted in SOFA air zone. The chemical reactions in the main combustion zone are mainly $\mathrm{C}$ reacting with $\mathrm{O}_{2}$ and producing $\mathrm{CO}$ and $\mathrm{CO}_{2}$, as well as the reduction reaction of $\mathrm{CO}_{2}$, and different chemical reaction dominates at different height in the furnace.

(3) Analyzing the component change and reactions along the direction of the flow ejected from burners find that volatile and char start burning almost at the same time, volatile release rate reach peak value before the char combustion rate, and volatile release has promoting and blocking effects on char combustion at the same. Before the release rate of the volatile reach the peak value, the blocking effect was dominant, and the promoting effect was dominant after the release rate reach the peak. Volatile and char combustion make temperature increase sharply, and then rise slowly after char combustion rate reach to peak value. No matter it is volatile release, or char combustion, the second layer AireJet burner is earlier than the first layer DRB-4Z burner because of structure difference. 
(4) All three methods, raising primary air temperature, lower aircoal ratio, and increasing swirl intensity, can improve char burnout rate and reduce $\mathrm{CO}$ concentration at the outlet of furnace without a substantial increase in the yield of $\mathrm{NO}_{x}$, so as to improve the combustion efficiency, optimize the combustion.

\section{ACKNOWLEDGEMENTS}

This work was financially supported by National Natural Science Foundation of China (No. 51476103), Public welfare scientific research projects of Shanghai Municipal Bureau of Quality and Technical Supervision (No. 2012-41), Innovation Program of Shanghai Municipal Education Commission (No. 14ZZ134) and Shanghai Pujiang Program (No. 14PJ1407000).

\section{REFERENCES}

Ariyama, T., Sato, M., Yamakawa, Y., Yamada, Y., and Suzuki, M., 1994, "Combustion Behavior of Pulverized Coal in Tuyere Zone of Blast Furnace and Influence of Injection Lance Arrangement on Combustibility," ISIJ International, 34(6), 476-483.

Chen, J. P., Yang, Y. P., Wang, Z. R., Deng, G. F., Chen, Z. C., and Cai, S., 2002, "To Raise the Combustion Efficiency of $410 \mathrm{t} / \mathrm{h}$ Pulverized Coal-Fired Boiler," Electric Power, 09, 7-9.

http://dx.doi.org/doi:10.3969/j.issn.1004-9649.2002.09.002.

Cui, C. X., 2013, “Analysis of Incomplete Combustion Heat Loss Form and the Measures for Improving the Thermal Efficiency in Thermal Power Plant Coal-Fired Boiler," Chemical Enterprise Management, 20, 71-72. http://dx.doi.org/doi:10.3969/j.issn.1008-4800.2013.20.063.

Dou, H. J., Chen, Z. B., and Huang, J. Q., 2007, "Numerical Study of Anthracite Combustion Mechanism in a 2000 t/d Precalciner," Computers and Applied Chemistry, 24(12), 1599-1606.

http://dx.doi.org/doi:10.3969/j.issn.1001-4160.2007.12.004.

He, P., Gu, H. Y., Mei, S. X., and Xie, J. L., 2009, "Research on Numerical Simulation of Pulverized Coal Combustion in Rotary Kiln," Cement Guide for New Epoch, 5, 29-32.

http://dx.doi.org/doi:10.3969/j.issn.1008-0473.2009.05.008.

Jia, B. H., and Yang, Z. X., 2014, "Current Situation and Development of Energy Saving in Power Plant Boiler," Urban Construction Theory Research (Electronic Version), 4(36), 9241.

http://dx.doi.org/doi:10.3969/j.issn.2095-2104.2014.36.1371.

Li, Z. G., Guo, Z. C., and Tang, H. Q., 2013, "Mechanism and Kinetic Characteristics of Pulverized Coal Combustion in Two Phase Flow," Journal of Fuel Chemistry and Technology, 9(1), 33-39. http://dx.doi.org/doi:10.3969/j.issn.0253-2409.2013.01.006.

Liu, G. F., Wei, E. Z., Hao, W. D., and Guo, Y. Q., 2003, “A Model of Oxygen Concentration Variation Characteristics in Operation for Analysing Combustion Efficiency of Pulverized Coal Fired Boilers," Thermal Power Generation, 32(01), 15-19. http://dx.doi.org/doi:10.3969/j.issn.1002-3364.2003.01.005.

Lv, C. X., 2013, "Discussion on How to Improve the Boiler Efficiency and the Measures Taken," China Venture Capital, Z2, 58-59.

Sheng, H. S., 2013, "Several Measures to Improve the Efficiency of Coal-Fired Boiler Combustion," Guide of Sci-tech Magazine, 14, 404. http://dx.doi.org/doi:10.3969/j.issn.1007-1547.2013.10.365.

Sun, D. W., Jia, L. F., and Zhang, H. W., 2001, "Three Kinds of Boiler Efficiency," Heating, Ventilating \& Air Conditioning, 31(6), 23-24. http://dx.doi.org/doi:10.3969/j.issn.1002-8501.2001.06.006.

Wang, H. B., Dong, Y., and Quan, W. T., 1996, "Combustion Mechanism of Fuel Particles in an Internal Circulating Fluidized Bed," Journal of Harbin Institute of Technology, 28(01), 30-36.

Wang, S. H., Zhang, Y., and Gao, J. Q., 2010, "Cause Analysis and Countermeasures on Mechanical Incomplete Combustion Heat Loss in 450t/h CFB Boiler," Hebei Electric Power, 29(05), 35-37. http://dx.doi.org/doi:10.3969/j.issn.1001-9898.2010.05.014.

Xie, J. L., Xia, M. S., and Yi, M. H., 2005, "Numerical Simulation Study on Combustion Mechanism of Pulverized Coal in Calciner," Coal Science and Technology, 33(05), 48-51. http://dx.doi.org/doi:10.3969/j.issn.0253-2336.2005.05.015.

Wu, C. X., 2013, "On the Boiler Energy-saving Status and Development of Boiler Energy-Saving Technology of Power Plant," Energy and Energy Conservation, 11, 101-103. http://dx.doi.org/doi:10.3969/j.issn.2095-0802.2013.11.040.

Wu, X. F., 2014, "Study on Hydrodynamics in Circulating Fluidized Beds for Chemical-looping Combustion," Guangzhou Chemical Industry, 42(24), 144-146. http://dx.doi.org/doi:10.3969/j.issn.1001-9677.2014.24.056.

Yan, W. P., 1996, "Discussion on Developing Clean Coal Combustion Technology in Thermal Power Plant in China," Journal of Boiler Technology, 8, 24-28.

Zheng, G. B., Kang, T. H., Chai, Z. Y., and Yin, Z. H., 2006, “Applied the Rosin-Rammler Distribution Function to Study on the Law of Coal Dust Particle-Size Distribution," Journal of Taiyuan University of Technology, 37(3), 317-319. http://dx.doi.org/doi:10.3969/j.issn.1007-9432.2006.03.018. 